\title{
Lantana camara, An Alien Weed for Livestock: A Review
}

Adya Prakash Rath ${ }^{1}$, Krutanjali Swain ${ }^{2}$, Sumitra Panigrahi ${ }^{3}$, Abhilash Routray ${ }^{3}$, Sipra Panda ${ }^{4}$, Saraswat Sahoo $^{5}$ and Subha Ganguly ${ }^{6 *}$

${ }^{1}$ National Research Centre on Equines, Sirsa Road, Hisar-125 001, Haryana, India.

2Department of Veterinary Parasitology, Lala Lajpat Rai University of Veterinary and Animal Sciences, Hisar, Haryana, India. ${ }^{3}$ Department of Veterinary Public Health and Epidemiology, Lala Lajpat Rai University of Veterinary and Animal Sciences, Hisar-125 001, Haryana, India.

${ }^{4}$ College of Veterinary Science and Animal Husbandry, Orissa University of Agriculture and Technology (OUAT), Surya Nagar, Bhubaneswar, Odisha, India.

5Department of Animal Reproduction, Gynaecology \& Obstetrics, Orissa University of Agriculture and Technology (OUAT), Surya Nagar, Bhubaneswar, Odisha, India.

${ }^{6}$ Department of Veterinary Microbiology, Arawali Veterinary College, Jaipur Road, Bajor, Sikar, Rajasthan, India.

Received: November 20, 2016; Revised: November 28 2016; Accepted: December 13, 2016

Abstract: Lantana camara Linn. (Family: Verbenaceae), an ornamental shrub, a noxious weed grows in many tropical and subtropical parts of world. The common name of this ornamental shrub is lantana, wild/red sage, bunch berry, locally known as "Barophulnoo". The genus Lantana (Verbenaceae) as described by Linnaeus in 1753 contained seven species, six from South America and one from Ethiopia.

Key words: Lantana camara; Livestock; Weed

\section{Introduction}

Herbs have recently attracted attention as a health beneficial item or as a noxious material which is posing threat to human as well as health of livestock. Among many poisonous plants lantana has spread its detrimental effect to several livestock all over the world. Lantana (from the Latin lento, to bend) probably derives from the ancient Latin name of the genus Viburnum which it resembles a little in foliage and inflorescence. ${ }^{[1]}$

\section{Ecology}

L. camara is found in a variety of environments, including agricultural areas, forest margins and gaps, Riparian zones, grasslands, secondary forest and beachfronts. It is rarely found in natural or seminatural areas of forest as it is unable to compete with taller trees due to its lack of tolerance for shade. But it has the capacity to survive in drought, humidity $\&$ fire burnt condition. ${ }^{[2]}$

\section{Lantana poisoning in animals}

Field reports of lantana poisoning have been received from India, Australia, Cuba, Mexico, Brazil \& Fiji. Bos taurus cattle are more susceptible to lantana poisoning than Bos indicus cattle. Incidence varies from sporadic cases to heavy outbreaks during fodder scarcity due to drought/ flood. The estimates of economic losses in terms of mortality \& morbidity are not available for our country. Lantana acts as double edged weapon when a) Competitive advantage over other vegetation which serves as forages and cause loss of pasture.

b) Grazing in lantana infected pastures results in toxicosis.

\section{Chemical nature of toxins}

Basically the chemical nature of $L$. camara is hepatotoxic. Lantana hepatotoxins are pentacyclic triterpenoids called lantadenes. Some major lantadenes are lantadene A, B, C, D which have a common core structure of 22-hydroxyoleanonic acid. Minor lantadenes like reduced lantadene $\mathrm{A}$ and reduced lantadene $\mathrm{B}$ are also present in lantana leaves. Lantadene A has been found to be toxic in sheep and guinea pigs and is considered as major hepatotoxin in leaves. Oral administration of lantadene $\mathrm{C}$ induces severe toxicity in guinea pigs. ${ }^{[3,4]}$

\section{Mechanism of toxicity}

Ingestion of lantana foliage causes hepatotoxicity and secondary photosensitisation which is the chief mechanism underlying the damage caused by $L$. camara. It manifests its toxicity in 3 phases:-

$>$ Gastrointestinal (GIT) phase

$>$ Hepatic phase

$>$ Post- hepatic phase

Rumen contents become more toxic with passage of time possibly due to contents become more liquid thus enhancing absorption. Toxins are transported to liver

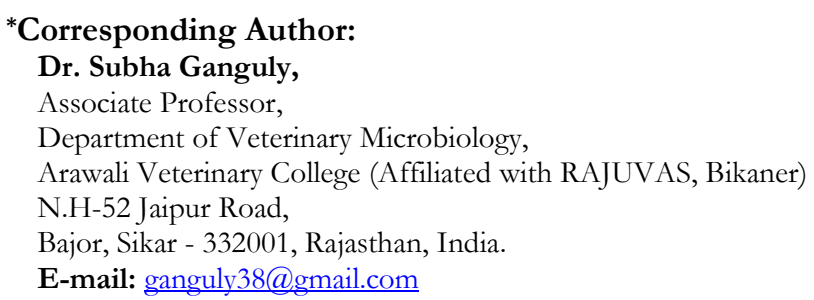

Department of Veterinary Microbiology,

N.H-52 Jaipur Road,

E-mail: ganguly38@gmail.com

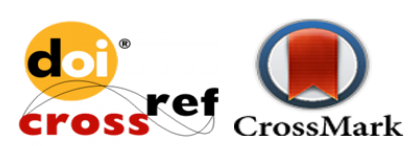


mainly in portal blood. Biotransformation of lantadene $A$ and $B$ observed in cecum of guinea pigs. Interaction of absorbed toxins with biomolecules in hepatocytes followed by cascade of biochemical reactions culminates in cholestasis. Guinea pigs and rats are used as lab animal models for biotransformation of lantadene A to reduced form. Lantana toxins cause paralysis of gall bladder and closure of bile canaliculi leading to decrease in bile flow. Cholestasis leads to regurgitation of bile which causes marked increase in levels of billirubin and phylloerythrin (degraded chlorophyll product) in blood. These bind proteins and undergo photochemical reactions which cause photosensitisation. ${ }^{[4,5]}$

\section{Clinical signs}

Ingestion of lantana foliage by grazing or oral administration leads to hepatotoxicity, cholestasis and photosensitisation. Toxic dose is $5 \mathrm{~g}$ (dry leaf powder) $/ \mathrm{kg}$ body weight. It leads to development of ruminal stasis. Animals may go off-fed within couple of hours \& become severely constipated. Within 24-48 $\mathrm{h}$ of ingestion they develop jaundice. Conjunctiva of eyes and mucous membranes of rectum is observed and vagina also becomes icteric. Eyelids become swollen and fissures appear on muzzle, ear tips \& nonhairy parts of body. Terminal renal failure occurs in severely affected animals. Photosensitisation is also observed in light-skinned animals when they are exposed to bright sunlight. There will be irritation of GI tract from lips to anus. Mildest form of poisoning to be noticed is the "pink nose" of Australian cattle. Other signs may include: sluggishness, weakness, and transient, sometimes bloody diarrhoea. In acute cases, death occurs in 2 to 4 days. ${ }^{[6,7]}$

\section{Gross lesions}

Skin of muzzle becomes inflamed, thickened, cracked. Same condition affecting mouth, producing ulcerative stomatitis with drooling of saliva and ultimately it leads to refusal to eat. At necropsy, principal lesions are basically acute haemorrhagic gastroenteritis with blood clots, pseudomembrane in the gut, marked icterus, subcutaneous oedema, subepicardial haemorrhages. The lesions in sheep produced by predetermined amounts of powdered leaves of lantana camara are basically icterus, Photosensitisation, swollen, ochre-coloured livers, distended gall bladders, and dry faeces in the colon, excessive mucus in remainder of large intestine, ascites and pulmonary oedema. ${ }^{[6]}$

\section{Microscopic lesions}

In less severely affected sheep, there is vacoulation of hepatic cells in the portal region of lobules with proliferation of bile ductules. In severely affected sheep, necrosis involved most of the liver cells with disorganisation of lobular architecture, proliferation of bile ductules and liver regeneration. There is necrosis of proximal convoluted tubules in kidney and cardiac muscle fibre. Distension of bile canaliculi and proliferation of villi into canaliculi is also observed. Characteristic blebs often formed as modification of wall of canaliculus. ER of hepatocytes is often fragmented and dispersed. ${ }^{[6,8]}$

\section{Diagnosis}

It is basically based upon history, clinical signs, clinical pathology and post-mortem lesions.

\section{Differential diagnosis}

Differential diagnosis of lantana toxicity from other hepatotoxicity and secondary photosensitisation should be done. It is settled by correlating clinical and biochemical picture with the flora present on the pasture where animal grazed prior to intoxication. Measurements of plasma bilirubin would support to be a case of lantana poisoning. Lantana camara var. aculeata bearing red flowers are more toxic than plant variety bearing pink flowers.

\section{Treatment}

No specific antidote is available till now, only symptomatic treatment is carried out. Always keep the animals in well shaded areas away from sunlight. Excessive amount of glucose saline solution intravenously is to be administered. Hepatoprotective agents to tone up liver should be given. A single dose of activated charcoal $(5 \mathrm{~g} / \mathrm{kg})$ to bind the toxin in the rumen is administered to prevent further absorption. H1 antihistaminics and antibiotics are administered to take care of photosensitisation lesions and secondary bacterial lesions.

\section{Aversion therapy}

It involves conditioning of animals before they are left for grazing in the pasture infested with poisonous plants. Yearling heifers were intraruminally infused with lithium chloride. The animal got conditioned to associating the lithium chloride-induced stress with ingestion of lantana foliage.

\section{Vaccination}

Antibodies against lantadenes A and B could be detected in sheep \& cattle after injection of conjugates of these compounds. Vaccination leads to decrease in severity of toxicity but protection is weak.

\section{Conclusion}

L. camara is a terror to the ecosystems as it chokes the native vegetation, destroys biodiversity, shows allelopathy and exerts toxic effects on ingestion. It demands concerted efforts for its management. The present study advocates that, instead of merely concluding $L$. camara a menace, it is wise to opt for its productive utilisation. The woody twigs can be crafted to aesthetic furniture. This can be developed as a cottage industry to provide livelihood to tribals and the unemployed, giving the economy a boost. Till now, perception is that the merits of $L$. camara score much lesser than the hazards. Time is ripe for bending the notion. 


\section{References}

1. Ambika, S.R., Poornima, S., Palaniraj, R., Sati, S.C. and Narwal, S.S. Allelopathic plants. 10. Lantana camara L. Allelopathy Journal 12 (2003): 147-62.

2. Ghisalberti, E.L. Lantana camara L. (Verbenaceae). Fitoterapia 71 (2000): 467- 86

3. Hart, N.K., Lamberton, J.A., Sioumis, A.A. and Saures, H. New triterpenes of Lantana camara. A comparative study of constituents of several taxa. Australian Journal of Chemistry 29 (1976): 655-71.

4. Kohli, R.K., Batish, D.R., Singh, H.P., and Dogra, K.S. Status, invasiveness and environmental threats of three tropical American invasive weeds (Parthenium hysterophorus L., Ageratum conyzoides L., Lantana camara L.) in India. Biological Invasions 8.7 (2006): 1501-10.

5. Black, H. and Carter, R.G. Lantana poisoning of cattle and sheep in New Zealand. New Zealand Vet J 33 (1985): $136-7$.
6. Sharma, O.P., Makkar, H.P.S., Dawra, R.K. and Negi, S.S. A review of the toxicity of Lantana camara (Linn.) in animals. Clin Toxicol 18 (1981): 1077-94.

7. Seawright, A.A., Everist, S.L. and Hrdlicka, J. Comparative features of Lantana, Myoporum and Pimelia toxicities in livestock. In: Keeler, R.F. and Tu, A.T., eds. Handbook of Natural Toxins, Vol. VI. Plants and fungal toxins. New York: Marcel Dekker, (1983), pp. 511-41.

8. Sharma, O.P. and Sharma, P. Natural products of the Lantana plant - The present and prospects. J Sci Ind Res 48 (1989): 471-8.

\section{Cite this article as:}

Adya Prakash Rath, Krutanjali Swain, Sumitra Panigrahi, Abhilash Routray, Sipra Panda, Saraswat Sahoo, Subha Ganguly. Lantana camara: an alien weed for livestock: A Review. Annals of Plant Sciences 5.12 (2016): 1472-1474.

\section{Source of support: Nil. \\ Conflict of interest: Nil}

